\title{
Effects of Dayak Onion Bulbs (Eleutherine bulbosa (Mill.) Urb) on Bone Development of the Hipoestrogen Model Rat
}

\author{
Anton Bahtiar*, Riza Annisa
}

\section{Anton Bahtiar*,} Riza Annisa

Department of Pharmacology, Faculty of Pharmacy, Universitas Indonesia, Depok, 16424 West Java, INDONESIA.

\section{Correspondence}

Anton Bahtiar

Department of Pharmacology, Faculty of Pharmacy of Universitas Indonesia, Faculty of Pharmacy, Universitas Indonesia, Kampus Baru UI, Depok, 16424, INDONESIA.

Phone No: +62 217864049

E-mail: anton.bahtiar@ui.ac.id

\section{History}

- Submission Date: 13-09-2017.

- Review completed: 20-11-2017;

- Accepted Date: 19-12-2017

DOI : 10.5530/pj.2018.2.52

Article Available online

http://www.phcogj.com/v10/i2

\section{Copyright}

(C) 2018 Phcog.Net. This is an openaccess article distributed under the terms of the Creative Commons Attribution 4.0 International license.

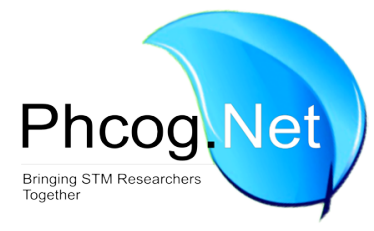

\begin{abstract}
Background: Eleutherinol is a naphtoquinone derivative that has strong affinity to bind with estrogen alpha receptors (ER $\alpha$ ). This compound can be found in Dayak Onion Bulbs (Eleutherine bulbosa Mill.). Objective: The purpose of this study is to analyze the effects of Dayak Onion Bulbs extract on the growth of the bone of hypoestrogen model rat. Methods: A total of 36 female white rats of Sprague-Dawley were divided into 6 groups. All 6 groups receive $\mathrm{CMC} \mathrm{Na} 0,5 \%$ (sham group), CMC Na 0,5\% (negative group), tamoxifen (positive group), three level of dayak onion bulbs extract doses namely dose $8 \mathrm{mg} / 200 \mathrm{~g}, 12 \mathrm{mg} / 200$ $\mathrm{g}$, and $18 \mathrm{mg} / 200 \mathrm{~g}$. All groups, except the sham, is ovariectomized to obtain the conditions of hypoestrogen. After ovariectomy, all rats were evaluated for the success of ovariectomy on day 35 , followed by the administration of the extracts by oral administration for 21 days. After 21 days administration, the level of bone calcium, bone weight, and bone length were measured by Atomic Absorption Spectrophotometry. Results: Dayak onion bulbs extract at dose 3 (18 mg/200 g BW) could increase significantly bone calcium level, bone weight, and bone legnth of hypoestrogen rat. Conclusion: The results showed that Dayak onion bulbs extract could be developed to be a drug for menopause woman in the future.
\end{abstract}

Key words: Dayak onion bulbs, Bone calcium level, Bone weight, Bone length, Hypoestrogen, Menopause.

\section{INTRODUCTION}

Menopause is a condition of low estrogen hormone produced by the ovaries in the end of the menstrual cycle. Menopause occurs in women in the age range of 45 and 55 years old. ${ }^{1}$ Decreased levels of estrogen hormone in postmenopausal women will show some symptoms in various organs. Some of the symptoms that may arise can be classified into short-term symptoms and long-term symptoms. Short-term symptoms consist of vasomotor symptoms, psychological symptoms, urogenital symptoms, and symptoms on the skin. Meanwhile, long-term symptoms consist of osteoporosis, coronary heart disease, and atherosclerosis. ${ }^{2,3}$ In pre-menopausal women, estrogen will suppress bone resorption, so at the time of postmenopause with decreased levels of estrogen hormone, an increase in osteoclast formation results from an increase in the number of cytokines such as Tumor Necrosis Factor Alpha (TNF- $\alpha$ ). This condition will continuously lead to osteoporosis. ${ }^{4}$ Osteoporosis is a bone disease that characterized by the decreased of bone mass (bone density) as a whole due to the body's inability to regulate mineral content in bone and accompanied by the damage of bone constituent components so resulting in bone loss. The cause of osteoporosis is the presence of disorders in bone metabolism. Bone metabolism may be impaired due to various factors, such as lack of estrogen, low intake of calcium and vitamin $\mathrm{D}$, and side effects of some drugs. ${ }^{5}$

Various symptoms that arise after menopause can be overcome with the use of hormone replacement therapy (HRT). Hormone replacement therapy works as non-selective and agonist to all estrogen receptors, thus increasing the proliferation of all estrogenreceptor cells. With the technological advances in the field of genetic technology, found a class of drugs that work very unique, in some organs as agonists and in other organs estrogen antagonist (tissue-selective). This class is known as the selective estrogen receptor modulator (SERM). SERM drugs consist of 2 generations, namely tamoxifen (generation 1) and raloxifene ( $2^{\text {nd }}$ generation). Tamoxifen is an agonist in the endometrium and bone, commonly used for the treatment of breast cancer and postmenopausal hormonal therapy. However, the effects of endometrial agonists on these drugs can lead to endometrial proliferation. Therefore, the second generation of raloxifene was found to be the same but antagonist to endometrium. ${ }^{6}$ The other treatment which is comes from plants and almost has the same activity as estrogen in the body called phytoestrogens. Phytoestrogens are molecules of plants that are structurally similar to endogenous estrogens. Phytoestrogens can 
Bahtiar, et al.: Dayak Onion Bulbs Extracts for Bone Development.

Table 1 : Animal treatment.

\begin{tabular}{ccc}
\hline Group & $\begin{array}{c}\text { Number of } \\
\text { rats }\end{array}$ & Treatment \\
\hline Sham & 6 & Surgery without ovaries removal $+\mathrm{CMC} \mathrm{Na} 0.5 \% 3 \mathrm{ml} / 200 \mathrm{~g} \mathrm{bw} \mathrm{per} \mathrm{oral}$ \\
Negative Control & 6 & Ovariectomy $+\mathrm{CMC} \mathrm{Na} 0.5 \% 3 \mathrm{ml} / 200 \mathrm{~g} \mathrm{bw}$ per oral \\
Positive Control & 6 & Ovariectomy + tamoxifen dose $0.36 \mathrm{mg} / 200 \mathrm{~g} \mathrm{bw} \mathrm{in} 3 \mathrm{ml}$ of aquadest per oral \\
OVX-Dose 1 & 6 & Ovariectomy $+3 \mathrm{ml}$ suspension of Dayak Onion bulbs extract dose $8 \mathrm{mg} / 200 \mathrm{~g} \mathrm{bw} \mathrm{in} \mathrm{CMC} \mathrm{Na} \mathrm{solution} 0.5 \%$ per oral \\
OVX-Dose 2 & 6 & Ovariectomy $+3 \mathrm{ml}$ suspension of Dayak Onion bulbs extract dose $12 \mathrm{mg} / 200 \mathrm{~g}$ bw in CMC Na solution $0.5 \%$ per oral \\
OVX-Dose 3 & 6 & Ovariectomy $+3 \mathrm{ml}$ suspension of Dayak Onion bulbs extract dose $18 \mathrm{mg} / 200 \mathrm{~g}$ bw in CMC Na solution $0.5 \%$ per oral \\
\hline
\end{tabular}

directly bind to estrogen receptors (RE) and compete with endogenous estrogens, so they can have both estrogenic and anti-estrogenic effects. Phytoestrogens have these two properties and expected can be used as an alternative therapy for postmenopausal symptoms. ${ }^{7}$

One of the plants that containing compounds with estrogenic activity is the Dayak Onion Bulbs. Dayak onion bulbs is from Central Kalimantan. ${ }^{8}$ This plant comes from the family Iridaceae which is empirically used to cure breast cancer. ${ }^{9}$ This is scientifically proved by In silico study in 2014 which states that Dayak onion bulbs contains derivatives of naftokuinon compound, eleutherinol, that antagonist in estrogen alpha receptors (ER- $\alpha$ ) in breast. ${ }^{8}$ These compounds are expected selective and agonist in estrogen receptors in other tissues such as bone and blood vessels, so it can be used as an alternative therapy to treat postmenopausal syndrome. Therefore, further research is needed to prove the effects of Dayak onion bulbs scientifically on overcoming postmenopausal syndrome seen from the bone density by increasing levels of calcium, bone weight, and bone growth.

\section{MATERIALS AND METHOD}

\section{Plant Materials}

Fresh bulbs were found and collected from Palu, Central Sulawesi, Indonesia and were identified by the Technical Service Unit of Biological Resources, Tadulako University, Central Sulawesi, Indonesia, with the voucher specimen number 65/UN.28.UPT-SDHS/LK/2016.

\section{Preparation of plant materials}

The $70 \%$ ethanolic extract of dayak onion bulbs are made by maceration by $70 \%$ ethanol solvent. The $5 \mathrm{~kg}$ of dayak onion bulbs was soaked with 1 liter of $70 \%$ ethanol solvent for $24 \mathrm{~h}$, stirring was carried out for $3 \mathrm{~h}$ and then the stirred extract was allowed to stand for $24 \mathrm{~h}$. Furthermore, all the obtained maserates were evaporated with rotary evaporator at temperature of $50^{\circ} \mathrm{C}$ to obtain a viscous extract.

\section{Animal Study}

White female Sprague-Dawley rats that were used in this experiment were obtained from the Bogor Agricultural Institute (IPB), weighing less than 100 gs, 5 weeks of age as much as 36 individuals. Before treatment, the animals were acclimatized for 1 week in standard animal cages to adapt the rats to the new environment and reduce stress. During the acclimatization conducted, observation of the general state of test rats and weighing was done every day. Permission and approval for animal studies were obtained from ethics commitee in Faculty of Medicine, Universitas Indonesia. (Approval No. 44/UN2.F1/Ethics/2017)

\section{Ovariectomy method}

All groups except sham group performed ovarian removal process (ovariectomy). Before being ovariectomized, rats were weighed, then anesthetized with ketamine $120 \mathrm{mg}$ / kg body weight of rat intramuscularly.
After anesthetized, rats were scaled around the surgical area (right and left dorsolateral, $\pm 2 \mathrm{~cm}$ above the groin, with a distance of $\pm 1.5 \mathrm{~cm}$ from the spine of $2.5 \mathrm{~cm}^{2}$ ). Incision in the surgical area (slightly indented into the body if held or $2 \mathrm{~cm}$ following the spine with a distance of $1.5 \mathrm{~cm}$ from the spine). Look for the ovaries (shaped like grapes and under the colon) then cut and set aside. Apply betadine to open wounds, sew the skin in 1 knot and outer skin 2-3 knots, then apply an antiseptic solution. After that, apply betadin to the stitch area. The same procedure is repeated to take the right ovary. Single cage is prepared for each mouse, dialed with tissue and clean paper. Ovariectomized rats are placed in a single cage that has been prepared. Apply wounded rats with povidon iodin. Keep the cage clean. The tissue layer in the rat cage are replaced daily to maintain the cleanliness of the cage during rat recovery.

\section{Dosage and Treatment Duration}

Selection of dose and duration of treatment provision is based on the results of previous studies. Dayak onion bulbs extract dose $8 \mathrm{mg} / 200 \mathrm{~g}$ bw was set to be dose I, $12 \mathrm{mg} / 200 \mathrm{~g}$ bw was set to be dose II, and $18 \mathrm{mg} /$ $200 \mathrm{~g}$ bw was set to be dose III.

\section{Animal grouping and treatment}

Research was conducted using 36 female rats that were weighed and randomly divided into six treatment group of 6 rats as follows: sham, negative control, positive control, negative control, dose 1, dose 2, and dose 3 as shown in Table 1 . Successively, all 6 groups receive CMC Na 0,5\%, CMC $\mathrm{Na} 0,5 \%$, tamoxifen, bawang dayak bulbs extract at a dose $8 \mathrm{mg} / 200 \mathrm{~g}$ bw , bawang dayak bulbs extract at a dose $12 \mathrm{mg} / 200 \mathrm{~g}$ bw , and bawang dayak bulbs extract at a dose $18 \mathrm{mg} / 200 \mathrm{~g}$ bw. All groups, except the sham, is ovariectomized to obtain the conditions of hypoestrogen. After ovariectomy, all rats checked for ovariectomy success on day 35 , followed by the administration of the test substance orally for 21 days on day 36 . After 21 days administration, measured level of bone calcium.

\section{EVALUATION OF PARAMETERS}

\section{Rat tibia bone calcium}

At the end of the experiment, all experimental animals were sacrificed with ether to remove the left tibia bone. Surgery is performed using a surgical tool by cleansing bone from tissue and fat attached. Then, cut from the knee joints to the rat ankle joints. The preparation process of the bone's sample that has been isolated is needed to be done first before doing the destruction process. The isolated bone was dried in a $100{ }^{\circ} \mathrm{C}$ oven for $3 \mathrm{~h}$. After that, the bone is weighed. Then put it in a furnace with a temperature of $700^{\circ} \mathrm{C}$ for $4 \mathrm{~h}$. Bones that have become white ash, crushed until smooth.The ash powder is then fed into the erlenmeyer flask and dissolved in $20 \mathrm{ml}$ of $25 \% \mathrm{HCl}$, then the solution is heated over the hotplate until the $25 \%$ HCL volume is reduced to $1 / 4$ gourd. Furthermore, $10 \% \mathrm{HCl}$ was added as much as $20 \mathrm{ml}$, then reheated until $10 \%$ $\mathrm{HCl}$ volume was reduced to $1 / 4$ fill, then put into a $50 \mathrm{ml}$ measuring flask. After that, the aquadest is added to $50 \mathrm{ml}$ on the measuring flask, then 


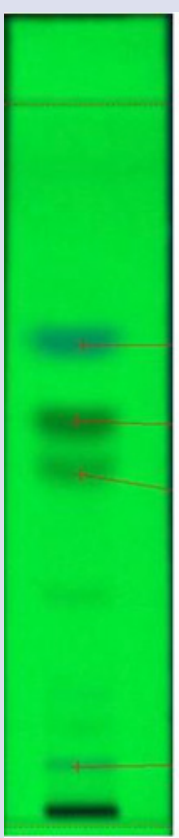

A

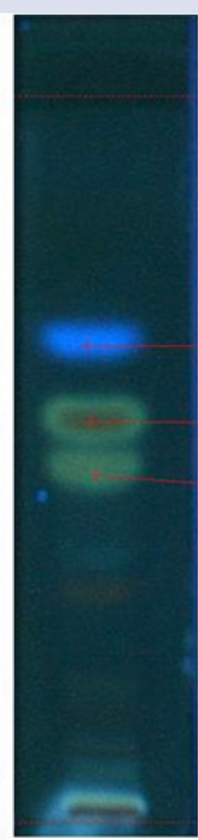

B

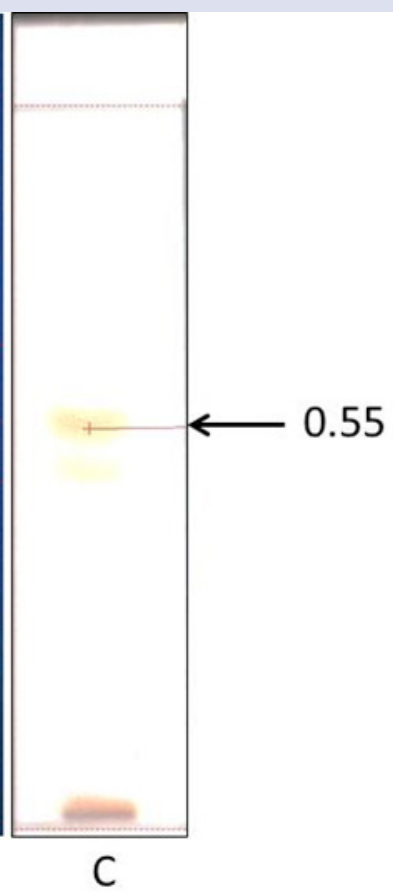

Figure 1: TLC of Dayak Onions extracts using mobile phase Chloroform:methanol (7:1). Black arrow indicated naphtoquinone. A. UV 256, B. UV 366, C. $10 \% \mathrm{KOH}$.

filtered.Pipette $1 \mathrm{ml}$ of main solution, put into a $100 \mathrm{ml}$ measuring flask, sufficient with aquadest to $100 \mathrm{ml}$. Subsequently the test solution measured its calcium content with an atomic absorption spectrophotometer at a wavelength of $422.7 \mathrm{~nm}$.

\section{The weight and length of rat tibia bone}

The rat tibia bone is cleaned from tissue that attached and dried by oven at $100^{\circ} \mathrm{C}$ for $3 \mathrm{~h}$. Furthermore, the bone is weighed using an analytical scale. After that, measured the length of each bone of each group.

\section{Statistical Analysis}

Data obtained from this work were analyzed statistically using SPSS. Analysis conducted were homogeneity (Levene test) and test of normal distribution (Shapiro-Wilk test). To see the relationship between the treatment groups, one-way analysis of variance (ANOVA) was conducted followed by an analysis of Significant Difference test (LSD). Differences between means will be considered significant at $5 \%$ level of significance i.e $P<0.05$.

\section{RESULTS}

\section{Extraction and Identification}

Dayak onion bulbs were extracted in the Research Institute of Spices and Medicinal Plants of Indonesia by using maceration method. Fresh of bulbs as much as $5000 \mathrm{~g}$ yield $70 \%$ ethanolic extract of dayak onion bulbs as much as $188,7 \mathrm{~g}$ or has $3,77 \%$ of rendemen. By phytochemistry screening, the $70 \%$ Ethanolic extract of of Dayak onion bulbs contains : flavonoids, tannins, alkaloids, saponins, triterpenoids, and quinones. We also identified naphtoquinone content of the extract by thin layer chromatography and found that spot for naphtoquinone on the Rf 0.83 similar with the previous research as shown in Figure 1.

\section{Bone calcium level measurement}

At the end of the treatment, all the rats in each group were sacrificed and removed their left tibia bone to determine the bone calcium level. The bone samples were measured by an atomic absorption spectrophotometer at a wavelength of $422.7 \mathrm{~nm}$, and then the results can be seen in Table 3 .

At the end of treatment, after cleansing of the attached tissue, the rat's tibia bone was dried at $100^{\circ} \mathrm{C}$ for $3 \mathrm{~h}$. After that, the bone is weighed with analytic scales. The results of bone weight measurements can be seen in Table 3. Tibia rat length measurements were performed after the weight of the bone was weighed. The results of rat bone tibia length measurement can be seen in Table 3 .

\section{DISCUSSION}

\section{Extraction and Identification}

Dayak onion bulbs were extracted in the Research Institute of Spices and Medicinal Plants by using maceration method because its simple, safe, and does not change the compounds contained. In previous study it is known that eleutherinol compounds can be drawn using methanol solvents (polarity 5,1). ${ }^{10}$ Thus, in this study we used solvent with polarity approaching methanol which is $70 \%$ ethanol (polarity 5,2 ). The choice of ethanol as a solvent is also based on the polar properties of ethanol so it is expected to attract the desired compounds, and also in terms of safety for animals and humans.

The 70\% Ethanolic extract of of Dayak onion bulbs contains flavonoids, tannins, alkaloids, saponins, steroids / triterpenoids, and quinones. Flavonoid evaluation was done using Shinoda test by addition of Magnesium powder and $1 \mathrm{ml}$ of concentrated $\mathrm{HCl}$. Furthermore, amyl alcohol was added, shaken with strength, and allowed to separate. The final result is the formation of red or orange yellow color that indicates the presence of flavonoids.

Identification of tannin using reaction with $1 \% \mathrm{FeCl} 3$ solution and resulted in a blackish-green color in the extract indicating the presence of a condensed tannin. The addition of $\mathrm{FeCl}^{3}$ may react with one of the hydroxyl groups on the tannin.

Dayak onion bulbs extracts also positively contain saponins as indicated by the formation of foam during identification. This shows the presence of compounds that have the ability to form foam in water that hydrolyzed into glucose and other compounds. For alkaloid identification, dayak onion bulbs extracts gave positive results when the Mayer reagents were added, white precipitate was formed. Then, with bouchardat reagent, dayak onion bulbs extract gave positive results by the formation of brown precipitate, and the Dragendorf reagent characterized by the formation of orange precipitate.

Identify triterpenoids / steroids using Lieberman-Burchard reagents. Filtrate of dayak onion bulbs extract was added by Lieberman-Burchard reagent and yielded a red precipitate then turned into a blue green indicating the presence of triterpenoids / steroids. For the identification of the quinone, filtrate of dayak onion bulbs extracts were added $5 \%$ sodium hydroxide and resulted in a positive red color.

\section{Bone calcium level measurement}

According to the Table 2, the average of bone calcium levels from highest to lowest is the third dose, dose 2, sham, positive control, a dose of 1, and a negative control.

The average of bone calcium levels with dose variation showed that there was a difference between dose group 1, 2 and 3. Statistical analysis showed 
Bahtiar, et al.: Dayak Onion Bulbs Extracts for Bone Development.

Table 3 : Tibia bone analysis.

\begin{tabular}{ccccccc}
\hline Treatment & \multicolumn{5}{c}{ Average \pm SD } \\
& Sham & $\begin{array}{c}\text { Negative } \\
\text { Control }\end{array}$ & $\begin{array}{c}\text { Positive } \\
\text { Control }\end{array}$ & Dose 1 & Dose 2 & Dose 3 \\
\hline $\begin{array}{c}\text { Bone Calcium } \\
\text { Concentration }(\mathbf{g} / \mathbf{1 0 0} \mathbf{g})\end{array}$ & $45.39 \pm 4.96$ & $35.99 \pm 3.70^{*}$ & $44.41 \pm 4.75^{*}$ & $43.93 \pm 3.20^{*}$ & $45.634 .11^{*}$ & $49.05 \pm 1.54^{*}$ \\
Tibia Bone Weight $(\mathbf{m g})$ & $274.95 \pm 9.64$ & $181.45 \pm 6.27^{*}$ & $270.40 \pm 17.86^{*}$ & $267.12 \pm 8.41^{*}$ & $284.85 \pm 9.77^{*}$ & $286.38 \pm 11.40^{*}$ \\
Tibia Bone Length $(\mathbf{c m})$ & $3.30 \pm 0.06$ & $2.63 \pm 0.08^{*}$ & $3.27 \pm 0.08^{*}$ & $3.25 \pm 0.10^{*}$ & $3.30 \pm 0.06^{*}$ & $3.38 \pm 0.08^{*}$ \\
\hline
\end{tabular}

Note : ${ }^{*}$ significant different to Sham $(\mathrm{p}<0.05)$; \#significantly different to Negative control

Table 2: Qualitative analysis of Dayak onion bulbs extract.

\begin{tabular}{cc}
\hline Content & Result \\
\hline Flavonoids & + \\
Tanins & + \\
Alkaloids & + \\
Saponins & + \\
Triterpenoids & + \\
Quinones & + \\
\hline
\end{tabular}

that there was no significant difference between dose groups 1 and dose groups 2, but there are significant differences between the groups with a dose 1 and dose 3 . There was no significant difference between bone calcium level dose group 2 with group Dose 3.

The average of positive control group is much larger than the negative control group. This is evidenced by using statistical tests showing a significant difference between the positive control group and the negative control group. Furthermore, statistical analysis showed no significant difference between the levels of bone calcium positive control group with a dose groups 1 and 2 . However, there are significant differences between the levels of bone calcium positive control group with dose group 3. This shows that the dose of 3 significantly increased bone calcium levels, in which the calcium group calcium group 3 was higher than the positive control. High levels of calcium in the bone extract treatment group receiving 3 doses (18 $\mathrm{mg} / 200 \mathrm{~g} \mathrm{bw}$ ) showed that with the increase in dose of the extract then an increase in calcium levels in the bones. ${ }^{11}$

\section{Bone Weight Measurement}

Based on Table 2 above, the average bone weight from highest to lowest is dose 3 , dose 2, sham, positive control, dose 1 , and negative control. The average tibial bone of the sham group is much greater than the negative control group. This is evidenced by using statistical tests showing a significant difference between the weight of tibia bones of the sham group and the negative control group. This indicates that the process of ovariectomy is successful and those rats are actually in a hypoestrogen state. Estrogen plays a role in bone growth and inhibits osteoclast activity through osteoprotegerin stimulation. Low estrogen levels cause increased osteoclast activity resulting in reduced bone matrix, calcium bone and phosphate deposits also decreased.

The average tibia bone weight of the positive control group was much greater than the negative control group. This is evidenced by using statistical tests showing a significant difference between the positive control group and the negative control group. Furthermore, statistical analysis showed no significant difference between the tibial bone weight of the positive control group and the dose groups 1 and 2. However, there was a significant difference between the tibial bone weight of the positive control group and the dose group 3 . This indicated that dose 3 could significantly increased tibial bone weight. The high bone weight of the tibia in the group that received the treatment of the dose 3 extract $(18 \mathrm{mg} / 200 \mathrm{~g} \mathrm{BB})$ showed that with the increase of the dosage of extracts, the bone mass increased.

Bone matrix consists of organic elements, namely collagen fibers and inorganic elements which constitute two thirds of the weight of the bone. The inorganic element comprises calcium phosphate salts (85\%), calcium carbonate (10\%), and small amounts of calcium fluoride and magnesium chloride. Thus, the greater the bone, the greater the calcium content in bone.

\section{Bone Length Measurement}

Based on Table 2, the sequence values of the average bone length from highest to lowest were dose 3 , dose 2 and sham, positive control, dose 1 , and negative control. The average length of bone with those three dose variations in the extract dose treatment group showed that there was a difference. The result of statistical test showed that there was no significant difference between group of dose 1 and group of dose 2, but there was a significant difference between dose group 1 and group dose 3. There was no significant difference from statistic test of bone length of group dose 2 to group dose 3 .

The average bone length of the positive control group was much greater than the negative control group. This is evidenced by using statistical tests showing a significant difference between the positive control group and the negative control group. Furthermore, statistical analysis showed no significant difference between the bone length of the positive control group and the dose groups 1 and 2. However, there was a significant difference between the bone length of the positive control group and the dose group 3. This suggests that dose 3 may increase the length Bone significantly. The high bone length in the group that received the treatment of 3 dose extract ( $18 \mathrm{mg} / 200 \mathrm{~g} \mathrm{BB}$ ) showed that with increasing dosage of extract hence increase of tibia bone length size.

\section{CONCLUSION}

Based on the research that has been done, it can be concluded that the $70 \%$ ethanolic extract of dayak onion bulbs has an effect on bone density. It can be seen from the increase of the calcium, weight and the growth of the bone. The best effect was obtained from dose 3 (suspension of Dayak bulb extract $18 \mathrm{mg} / 200 \mathrm{~g} \mathrm{BB}$ ) seen from density parameter and bone growth.

\section{ACKNOWLEDGMENT}

We thank tp Directorate of Research and Community Service, Universitas Indonesia who gives financial support this research.

\section{CONFLICT OF INTEREST}

We declare that we have no conflict of interest. 


\section{ABBREVIATION USED}

ERa: Estrogen Receptor a; CMC Na: Carboxymethylcellulose Natrium; BW: Body Weight; TNF-a: Tumor Necrosis Factor Alpha; HRT: Hormone Replacement Therapy; SERM: Selective estrogen receptor modulator; OVX: Ovariectomy.

\section{REFERENCES}

1. Muharam R, Setiawan MW, Ikhsan M, Rizkinya HE, Sumapraja K. Depression and its link to other symptoms in menopausal transition. Middle East Fertility Society Journal. 2017. https://doi.org/https://doi.org/10.1016/j.mefs.2017.08.003.

2. Geukes M, Aalst MP, Nauta MCE, Oosterhof $H$. The impact of menopausal symptoms on work ability. Menopause: The Journal of The North American Menopause Society. 2012;19(3):278-82. https://doi.org/10.1097/ gme.0b013e31822ddc97.

3. Pacifici R, Brown C, Puscheck E, Friedrich E, Slatopolsky E, Maggio D,et al. Effect of Surgical Menopause and Estrogen Replacement on Cytokine Release from Human Blood Mononuclear Cells. Proceedings of the National Academy of Sciences of the United States of America. 1991;88(12):5134-8.

4. Santoro N. The menopausal transition. The American Journal of Medicine.
2005;118(Suppl12):8-13. https://doi.org/10.1016/j.amjmed.2005.09.008.

5. Symposium CF. Bone Structure and Metabolism. Novartis Foundation Symposia. Hoboken: Wiley. Retrieved from 2009. http://ncl.eblib.com/patron/FullRecord. aspx?p=739059.

6. DuSell CD, Umetani M, Shaul PW, Mangelsdorf DJ, McDonnell DP. 27-hydroxycholesterol is an endogenous selective estrogen receptor modulator. Mol Endocrinol (Baltimore, Md). 2008;22(1):65-77.

7. Pearce V, Nawaz Z, Xiao W, Wiedenfeld D, Boyle N, Smith D. 4-Ethoxymethylphenol: A novel phytoestrogen that acts as an agonist for human estrogen receptors. Journal of Steroid Biochemistry and Molecular Biology. 2003;84(4):431-9. https://doi.org/10.1016/S0960-0760(03)00064-5.

8. Amelia T, Pratiwi D, Tjahjono D. In silico Study of The Component of Eleutherine americana MERR on Human Estrogen Reseptor Alpha as Potential Anti-Breast Cancer. International Conference On Computation For Science And Technology 2014;3:6-9.

9. Bianchi C, Ceriotti G. Chemical and pharmacological investigations of constituents of Eleutherine bulbosa (Miller) Urb. (Iridaceae). Journal of Pharmaceutical Sciences. 1975;64(8):1305-8. https://doi.org/10.1002/jps.2600640809.

10. Gallo, et al. Polyketides from Eleutherine bulbosa. Natural Product Research 2010;24(16):1578-86.

11. Weitzmann MN, Pacifici R. Estrogen Deficiency and Bone Loss: An Inflammatory Tale. J Clin Invest.2006;116(5):1186-94

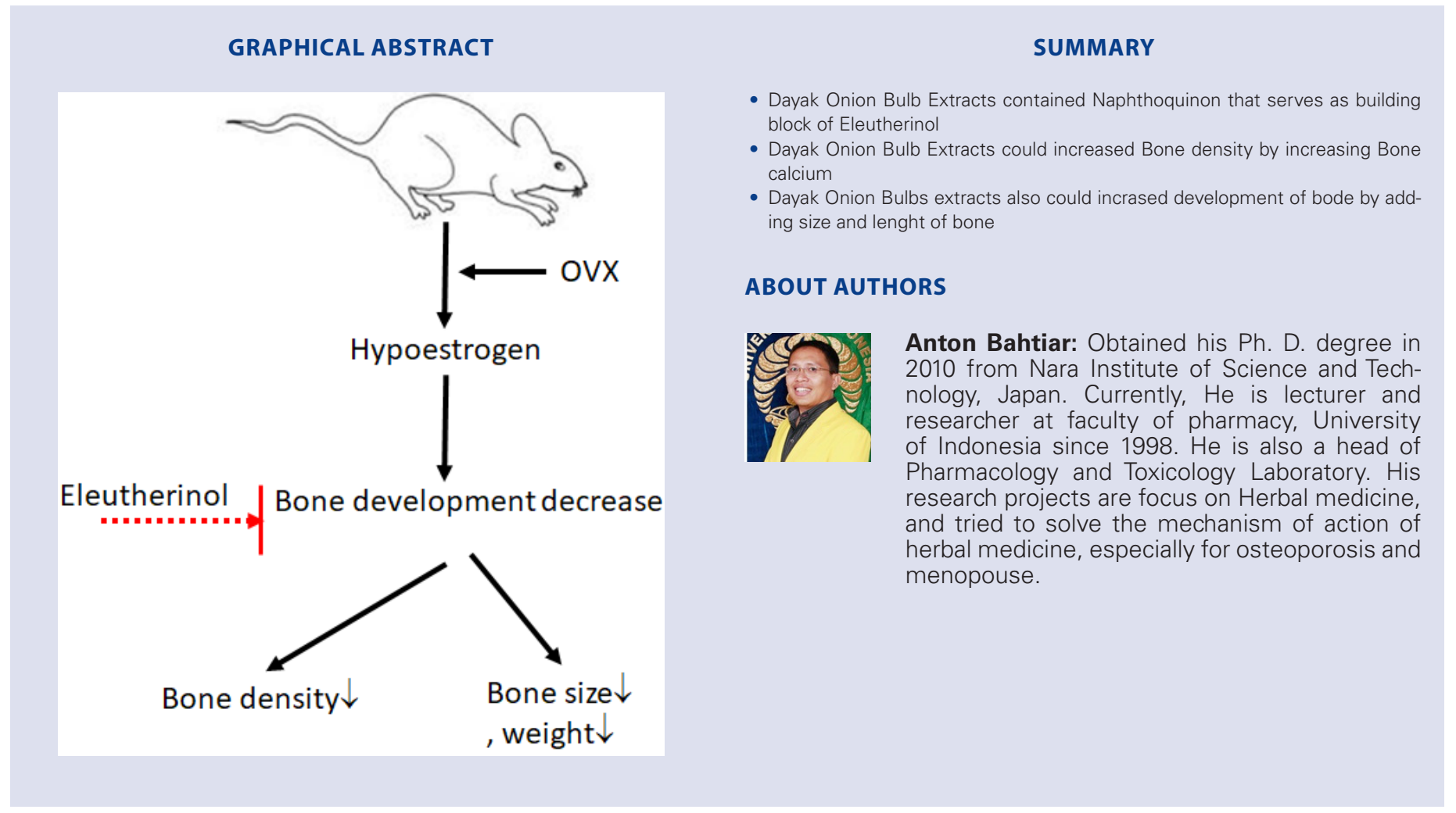

Cite this article: Bahtiar A, Annisa R. Effects of Dayak Onion Bulbs (Eleutherine bulbosa (Mill.) Urb) on Bone Development of the Hipoestrogen Model Rat. Pharmacog J. 2018;10(2):299-303. 